\title{
E-Course Design of Middle/MTs Teacher Training Using Google Classroom
}

\section{Refi Elfira Yuliani1, Heru $^{2 *}$ \\ 1,2 Prodi Pendidikan Matematika, FKIP, Universitas Muhammadiyah Palembang, Palembang, Indonesia}

\section{ART ICLE INFO}

Article history:

Received June 04, 202

Revised June 06, 2021

Accepted July 24, 2021

Available online August 25, 202

Kata Kunci:

E-Course, Google classroom

Keywords:

E-Course, Google classroom

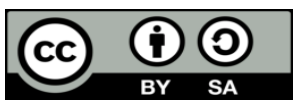

This is an open access article under the CC BY-SA license.

Copyright (C) 2021 by Author. Published by Universitas Pendidikan Ganesha.

\begin{abstract}
A B S T RA K
Kemampuan merancang pembelajaran daring merupakan keterampilan yang harus dimiliki guru dalam mengintegrasikan ICT pada pembelajaran. Permasalahan yang dihadapi guru dalam melaksanakan pembelajaran daring begitu kompleks dimulai dari akses internet sampai penggunaan aplikasi/software yang dapat digunakan dalam pembelajaran daring. Penelitian ini bertujuan untuk menghasilkan e-course pelatihan guru SMP/MTs menggunakan open source google classroom. Penelitian ini menggunakan metode penelitian pengembangan dengan evaluasi media menggunakan formative Evaluation Tessmer. Adapun yang dikembangkan dalam penelitian ini adalah media pelatihan guru dengan menggunakan google classroom. Subjek penelitian adalah guru SMP dan MTS dengan jumlah 28 orang yang terlibat selama kegiatan proses pelatihan. Instrumen yang digunakan dalam penelitian ini adalah angket. Angket yang diberikan pada para ahli, dan peserta ujicoba small group merupakan angket untuk menilai e-cource google classroom. Angket yang diberikan pada peserta ujicoba lapangan (field test) adalah untuk melihat efek potensial pembelajaran dengan menggunakan e-coursce terhadap kemampuan TPACK guru. Metode analisis data yang digunakan adalah deskriptif kualitatif.. Berdasarkan hasil penelitian yang telah dilakukan dapat disimpulkan bahwa e-course pelatihan guru menggunakan google classroom terkategori valid dan praktis. Kevalidan diperoleh dari penilaian dari ahli materi, media dan Bahasa dan one-to-one. Kepraktisan diporeleh dari hasil uji coba small group dengan menganalisis hasil angket yang disebar pada peserta uji coba small group sehingga diperoleh rerata presentase penilaian guru melalui angket sebesar 92,5\%. E-course memiliki efek potensial terhadap pencapaian TPACK guru dengan rerata persentase $82,46 \%$ yang tergolong baik. Berdasarkan hasil yang diperoleh dapat disimpulkan bahwa e-course pelatihan yang dikembangkan valid, dan praktis serta memiliki efek potensial terhadap pencapaian TPACK. Hal ini menunjukkan bahwa ecourse yang telah dikembangkan efektif.
\end{abstract}

\begin{abstract}
A B S T R A C T
The ability to design online learning was a skill that teachers in integrating ICT in Learning must possess. The problems faced by teachers in implementing online learning were complex, starting from internet access to the use of applications/software that can be used in online learning. This study aimed to produce an e-course for teacher training for SMP/MTs using the open-source google classroom. This research used a development research method with media evaluation using formative Evaluation Tessmer. As developed in this study was a teacher training media using google classroom. The research subjects were junior high school and MTS teachers, with 28 people involved during the training process activities. The instrument used in this research was a questionnaire. The questionnaire was given to the experts, and the participants of the small group trial were questionnaires to assess the e-course google classroom. The questionnaire given to the field test participants was to see the potential effect of learning using e-courses on the teacher's TPACK ability. The data analysis method used was descriptive qualitative. Based on the research results that have been done, it can be concluded that the e-course teacher training using google classroom was categorized as valid and practical. Validity was obtained from the assessment of the material, media, and language experts and was one-to-one. Practicality was obtained from the results of the small group trial by analyzing the results of the questionnaire distributed to the small group trial participants so that the average percentage of teacher assessment through the questionnaire was $92.5 \%$. E-course had a potential effect on teacher TPACK with an average rate of $82.46 \%$, classified as good. Based on the results obtained, it can be concluded that the developed training e-course was valid, practical, and had a potential effect on the achievement of TPACK. That was, the e-course that has been designed was effective.
\end{abstract}

\section{INTRODUCTION}

The ability to design online learning is a skill that teachers in integrating ICT in Learning must possess. The problems faced by teachers in implementing online learning are complex, starting from internet access to the use of applications/software that can be used in online learning. This study aims to 
produce an e-course for teacher training for SMP/MTs using the open-source google classroom. This research uses a development research method with media evaluation using formative Evaluation Tessmer.

One application that can be used to do the learning process online is to use Google Classroom. Google Classroom can be multiplatform, which can be through a computer and can be through a device. Teachers and students can visit the https://classroom.google.com site or download the app through the play store on android or through the app store on iOS with the keyword Google Classroom. The use is free of charge to be utilized as needed (Gunawan, F. I., \& Sunarman, 2018). The Google Classroom application assumes that learning goals can be more easily realized and meaningful. Therefore, using Google Classroom is very helpful and practical and provides new conveniences and challenges for teachers in delivering learning materials to students (Albashtawi \& Al Bataineh, 2020; Maharani \& Kartini, 2019). Through blended learning, students feel comfortable and active in constructing their knowledge. Teachers can take advantage of various features in Google Classrooms such as assignments, grading, communication, time-cost, archive course, mobile application, and privacy (Gunawan, F. I., \& Sunarman, 2018). In addition, Google classroom is also one of the most accessible LMS platforms because it provides a simple interface file for teachers and students to use (Vaganova, Smirnova, Vezetiu, Kutepov, \& Chelnokova, 2020).

The ability to design online learning is a skill that teachers must possess in integrating ICT in Learning. One form of ICT skills in learning, is Technological Pedagogical and Content Knowledge (TPACK). TPACK is a knowledge of the teacher's ability to integrate technology-based material character analysis and analysis on the pedagogical aspect (P. Mishra \& Koehler, 2006; Have Mishra, 2019; Schmidt et al., 2009). The TPACK framework has been widely used to measure the ability of prospective teachers and teachers (Kıray, Çelik, \& Çolakoğlu, 2018; Lin, Kuo, \& Ko, 2015; Misieng, Ramanair, \& Rethinasamy, 2018; Restiana \& Pujiastuti, 2019; Yulianti, Utami, Ridloand, \& Isdaryanti, 2021).

Integrating ICT in classroom learning is a challenge that is not easy to face. The teacher's attitude towards using technology in learning is under experience, complement, and level of knowledge (Msila, 2015; Termit Kaur \& Samli, 2014). Meanwhile, teachers' positive attitude and acceptance towards technology are essential factors for the successful use of technology in Learning (Kumar, Rose, \& D'Silva, 2008; Msila, 2015). Based on research conducted on prospective physics teacher students, students' technology capabilities are still low (Supriyadi, Bahri, \& Waremra, 2018). According to the results of Bahador et al. research on 120 high school math teachers, the technological ability of math teachers is still low and is at a simple stage (Bahador, Othman, \&Saidon, 2018). In addition, the integration of ICT in a teaching environment in math classes seems to remain far from initial expectations (Marbán \& Mulenga, 2019).

The problems faced by teachers in carrying out online learning are so complex. Starting from network limitations, hardware limitations such as smartphones or computers, teachers' ability to prepare smartphone/computer-based teaching materials, teacher ability to master open-source online learning such as google classroom, moodle, Kahoot, Edmodo, and others and many other technical problems that can reduce teacher performance in providing quality learning through online learning. The implementation of online learning during the covid-19 pandemic has various difficulties experienced by teachers, learners, and parents (Asmuni, 2020; Azzahra, 2020). The problems of teachers in the form of weak mastery and limited access to the supervision of learners, from learners in the form of lack of activeness following learning, limitations of supporting facilities and internet network access, while from parents in the form of limited time in accompanying their children during online learning. Various problems can be overcome by improving the competence of IT mastery, intensive supervision by involving the role of parents, and giving assignments manually.

Adapting a student-centered approach to online learning requires the development of new skills and changes to teaching practices. Failure to use technology in online learning can create insurmountable obstacles for teachers and students (Eichelberger \&Leong, 2019). Efforts to improve teacher competence need to be improved, primarily related to integrating technology in learning that the problems faced by teachers can be overcome. Integrating the digital learning technology not only through the development of technological infrastructure but also by supporting methodological training in the form of exercise for teachers who aim to improve their competence (Karolčík \& Čipková, 2017). Online training provided to teachers impacts teacher competence (Heru \& Yuliani, 2020; Ismail \& Imawan, 2021; Sulistiyono, 2020). Therefore, learning resources that teachers can use need to be propagated to help teachers improve their competence. Based on this, this study aims to develop e-course teacher training SMP / MTs using opensource Google Classroom that can potentially affect the achievement of TPACK Guru. So as to help teachers in implementing effective online learning. 


\section{METHOD}

This research used development research methods, media evaluation using formative evaluation (Tessmer, 1999). Developed in this study is E-Course teacher training using Google classroom. The research was conducted in the odd semester of 2020/2021 at SMP and MTS Muhammadiyah 1 Palembang. The development procedure in this research consists of 3 stages which consisted of the preliminary stage, prototyping phase, and assessment phase. Product evaluation in this study refers to formative assessment (Tessmer, 1998), including self-evaluation, prototyping (expert reviews and one-to-one, small group), and field tests.

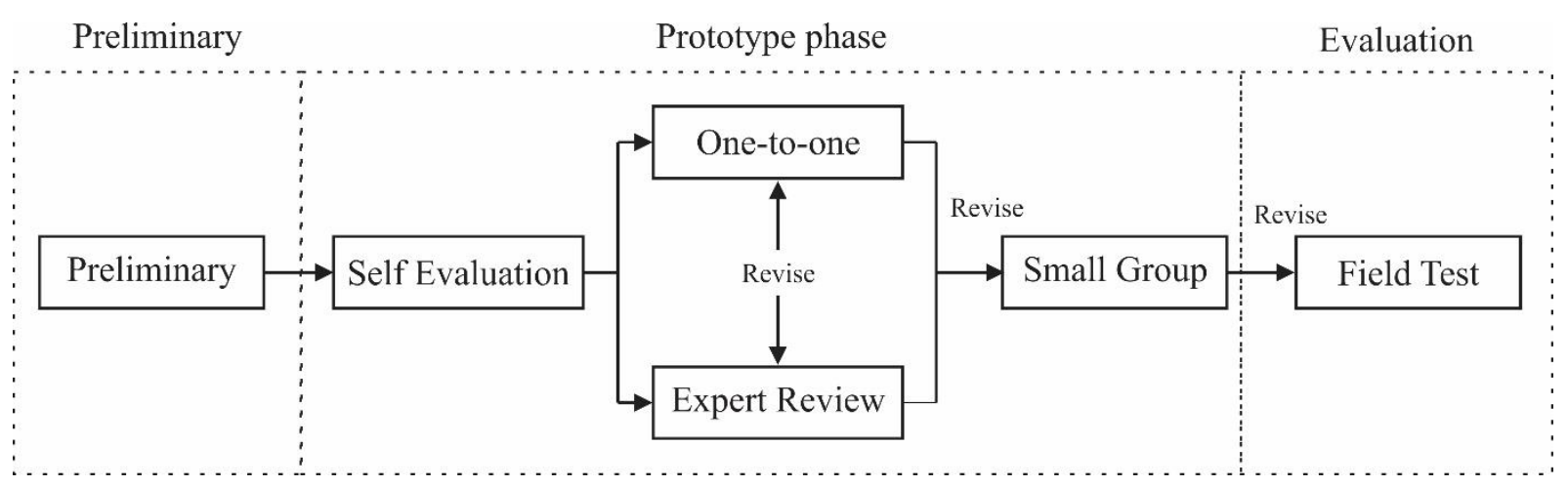

Figure 1. Teacher Training E-course Design Flow Using Google Classroom

The research subjects were Muhammadiyah Junior High School 1 and MTS Muhammadiyah 1 Palembang teachers, with 28 people. The subject was a teacher of diverse subjects. The methods of data collection used in this study were: 1) walkthrough, used to obtain data about the validity of the e-course made; 2) Observation, used to determine the practicality and effectiveness of the e-course developed, this observation was an observation of the teacher of the study subject to see the activeness and participation of the teacher during the training by observing the discussion on the google classroom forum; 3) Questionnaire, used to conclude e-course that has met the criteria of validity and practicality. The instrument used by validaotor to assess the learning media developed is an instrument that has been modified from BSNP (Akbar, 2016; Gita, Annisa, \& Nanna3, 2018; Manalu, Silaban, Silaban, \& Hutabarat, 2016). The Google Classroom e-course validation instrument grid is presented in Table 1.

Table 1. Google Classroom e-course validation instrument grid

\begin{tabular}{lll}
\hline Experts & Rated Aspects & Indicators \\
\hline Material & Content Feasibility Aspects & Suitability of Material with Learning Objectives \\
& & Material Accuracy \\
& Material Update \\
& Encourage Curiosity \\
& Presentation Feasibility Aspects & Presentation Technique \\
& Presentation Support \\
& Penyajian Pembelajaran \\
& Coherence of Thought \\
& E-course using google has been loaded with \\
& Technology Knowledge (TK) \\
& E-course using google has been loaded with \\
& Content Knowledge (CK) \\
& E-course using google has been loaded with \\
& Pedagogic Knowledge (PK) \\
& E-course using google has been loaded with \\
& Pedagogical Content Knowledge (PCK) \\
& E-course using google has been loaded with \\
& Technology Content Knowledge (TCK) \\
& E-course using google has been loaded with \\
& Technology Pedagogical Knowledge (TPK) \\
& E-course using google has been loaded with \\
& Technology Pedagogical Knowledge and Content
\end{tabular}




\begin{tabular}{lll}
\hline Experts & Rated Aspects & Indicators \\
\hline \multirow{2}{*}{ Media } & & Knowledge (TPACK) \\
& Accessibility & Google Classroom Accessibility \\
& & Modul Accessibility \\
& Display & Video Accessibility \\
& & Google Classroom Display \\
& & Modul Display \\
Language & Language Eligibility Aspect & Video Display \\
& & Straightforward \\
& & Communicative \\
& & Dialogic and Interactive \\
& & Conformity with Language Rules \\
\hline
\end{tabular}

Walkthrough data analysis techniques were analyzed descriptively as input to revise at each step of developing the suggestion prototype. The comment was used to improve or modify the generated media to get a valid one. Analysis of questionnaire data assessment of teacher response at the time of small group trial using Likert scale, then processed by way of percentage creation (Sugiyono, 2016). The results obtained by the above calculations helped develop conclusions with criteria as in Table 2.

Table 2. Practical Criteria

\begin{tabular}{cc}
\hline Persentage & Practical Criteria \\
\hline $0 \%-25 \%$ & No practical criteria \\
$25 \%-50 \%$ & Low enough to meet the practical aspect \\
$50 \%-75 \%$ & High enough to meet the practical aspect \\
$75 \%-100 \%$ & Meet the practical aspect \\
\hline
\end{tabular}

(Sugiyono, 2016)

In addition to being used for small groups, questionnaire analysis is also used in field tests. The teacher's TPACK questionnaire results were analyzed to see the ability to integrate TPACK in learning after participating in training in the e-course google classroom. The teacher achievement category is presented in Table 3.

Table 3. The Teacher TPACK Achievement Category

\begin{tabular}{cc}
\hline Interval Skor & Category \\
\hline $86-100$ & Very Good \\
$75-85$ & Good \\
$56-74$ & Enough \\
$40-55$ & Bad \\
$0-39$ & Very Bad \\
\hline
\end{tabular}

(Arikunto, 2012)

\section{RESULT AND DISCUSSION}

\section{Result}

At the prototyping phase stage obtained the Google Classroom e-course, which was then conducted a validity test by several experts/experts. Here are the validation results of experts. The level of practicality of the e-course was obtained from small group activities against five teachers. E-Course modules given in google classroom classes there were as many as eight modules. Module 1 on 21stcentury learning, module 2 scientific approach, module 3 of the nature of learning media, module 4 designing interactive learning multimedia, module 5 optimization of google classroom for online Learning, module 6 optimization of Edmodo for online learning, module 7 making interactive learning multimedia teaching materials using Microsoft Powerpoint and module 8 making online quizzes. In this small group, researchers gave questionnaires to teachers through a google form. This questionnaire was given to determine the practicality level of the Google Classroom e-course that has been developed. The questionnaire result was given to the teacher at the small group stage presented in Table 4. 


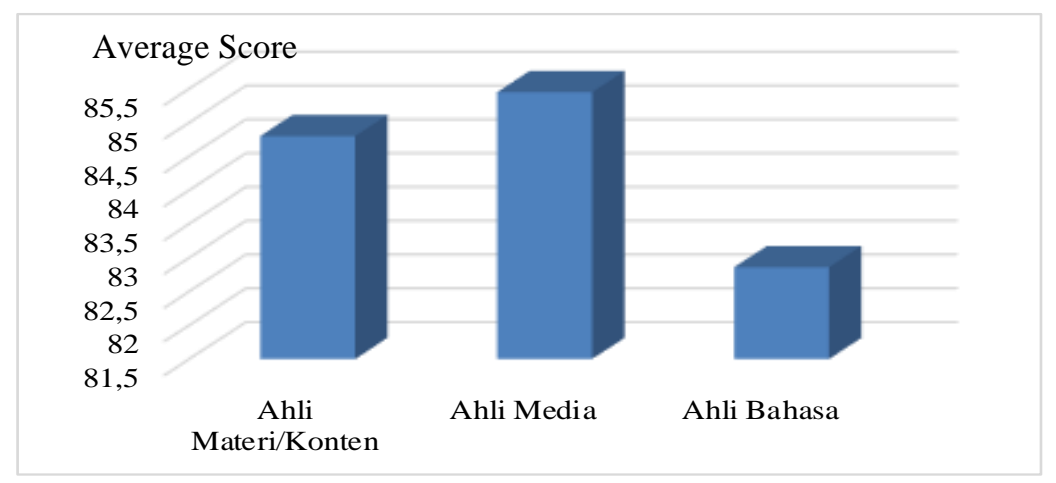

Figure 2. The Result of Expert Validation

Table 4. The result of Small Group Questionnaire Analysis

\begin{tabular}{ccc}
\hline Teacher Code & Total Score & \\
\hline G1 & 39 & 97.5 \\
G2 & 40 & 100 \\
G3 & 36 & 90 \\
G4 & 40 & 100 \\
G5 & 30 & 75 \\
\hline \multicolumn{2}{c}{ Average Percentage } & $\mathbf{9 2 , 5}$ \\
\hline
\end{tabular}

At the field test stage, the teacher involved 19 teachers who participated in training activities using the Google Classroom e-course. At this stage, we will see the potential effect of using Google Classroom e-courses on TPACK achievement. TPACK achievement instruments were filled by trainees (teachers) after conducting training activities. The result of the TPACK achievement score of trainees is presented in Table 5.

Table 5. The result of questionnaire analysis of the TPACK Field Test Achievement

\begin{tabular}{|c|c|c|c|c|}
\hline TPACK Components & $\begin{array}{l}\text { Statement } \\
\text { Items }\end{array}$ & $\begin{array}{l}\text { Total Teacher } \\
\text { Score per Item }\end{array}$ & $\begin{array}{c}\text { Percentage } \\
(\%)\end{array}$ & $\begin{array}{c}\text { Average } \\
\text { Percentage per } \\
\text { Component } \\
\end{array}$ \\
\hline \multirow{7}{*}{ Pedagogical Knowledge (PK) } & 1 & 66 & 87 & \multirow{7}{*}{85,57} \\
\hline & 2 & 62 & 82 & \\
\hline & 3 & 63 & 83 & \\
\hline & 4 & 68 & 89 & \\
\hline & 5 & 62 & 82 & \\
\hline & 6 & 67 & 88 & \\
\hline & 7 & 67 & 88 & \\
\hline \multirow{5}{*}{ Technological Knowledge (TK) } & 8 & 63 & 83 & \multirow[t]{2}{*}{84,2} \\
\hline & 9 & 63 & 83 & \\
\hline & 10 & 64 & 84 & \multirow{6}{*}{82,3} \\
\hline & 11 & 68 & 89 & \\
\hline & 12 & 62 & 82 & \\
\hline \multirow{3}{*}{ Content Knowledge (CK) } & 13 & 62 & 82 & \\
\hline & 14 & 62 & 82 & \\
\hline & 15 & 63 & 83 & \\
\hline \multirow{2}{*}{$\begin{array}{l}\text { Pedagogical Content } \\
\text { Knowledge (PCK) } \\
\text { Technological Content } \\
\text { Knowledge (TCK) }\end{array}$} & 16 & 63 & 83 & 83 \\
\hline & 17 & 62 & 82 & 82 \\
\hline \multirow{5}{*}{$\begin{array}{l}\text { Technological Pedagogical } \\
\text { Knowledge (TPK) }\end{array}$} & 18 & 64 & 84 & \multirow[t]{5}{*}{84,6} \\
\hline & 19 & 64 & 84 & \\
\hline & 20 & 65 & 86 & \\
\hline & 21 & 65 & 86 & \\
\hline & 22 & 63 & 83 & \\
\hline
\end{tabular}




\begin{tabular}{lcccc}
\hline TPACK Components & $\begin{array}{c}\text { Statement } \\
\text { Items }\end{array}$ & $\begin{array}{c}\text { Total Teacher } \\
\text { Score per Item }\end{array}$ & $\begin{array}{c}\text { Percentage } \\
\text { (\%) }\end{array}$ & $\begin{array}{c}\text { Average } \\
\text { Percentage per } \\
\text { Component }\end{array}$ \\
\hline & 23 & 64 & 84 & 88,57 \\
Technological Pedagogical and & 24 & 67 & 88 & 87 \\
Content Knowledge (TPACK) & 25 & 66 & 83 \\
& 27 & 63 & 92 \\
& 28 & 70 & 93 \\
\hline
\end{tabular}

Based on the research result obtained, validation that experts have done shows that the e-course that has been developed is well categorized after improvements to the advice of experts. Srangiven for $e$ course improvement is presented in Table 6.

Table 6. Expert Suggestions

\begin{tabular}{|c|c|c|}
\hline No. & Experts & Suggestions \\
\hline 1 & Media Expert & $\begin{array}{l}\text { Classes made are only one class; there is no need to create classes based } \\
\text { on material. Modules separate the material in Google Classroom to make it } \\
\text { easier for users (participants) to follow the course provided. }\end{array}$ \\
\hline 2 & Language Expert & There are still writing errors that need to be fixed \\
\hline 3 & Content Expert & $\begin{array}{l}\text { Materials / Principal contained in modules that can be accessed through } \\
\text { Google Classroom need to be added, not only discussing the Nature of } \\
\text { Learning Media, Optimizing Google Classroom, Making Interactive } \\
\text { Learning Multimedia. But it also needs to be added open-source-related } \\
\text { materials that teachers can use during online learning, such as Google } \\
\text { Form, Quizizz, Edmodo, Moodle. }\end{array}$ \\
\hline
\end{tabular}

The expert review stage was conducted in parallel with the one-to-one stage. The e-course design was piloted at a one-to-one stage with four teachers. Separately they were asked to observe, comment, and work on instructions given to classwork. Researchers interact and communicate online using the zoom meeting app to see the difficulties experienced during the training process. One-to-one results and expert reviews serve as the basis for revising prototype II. The draft E-Course module in the Google Classroom prototype II class was piloted in a small group conducted on five teachers. Based on expert advice, the material presented in google classroom should be made in one class, not separately like the display in Figure 3.

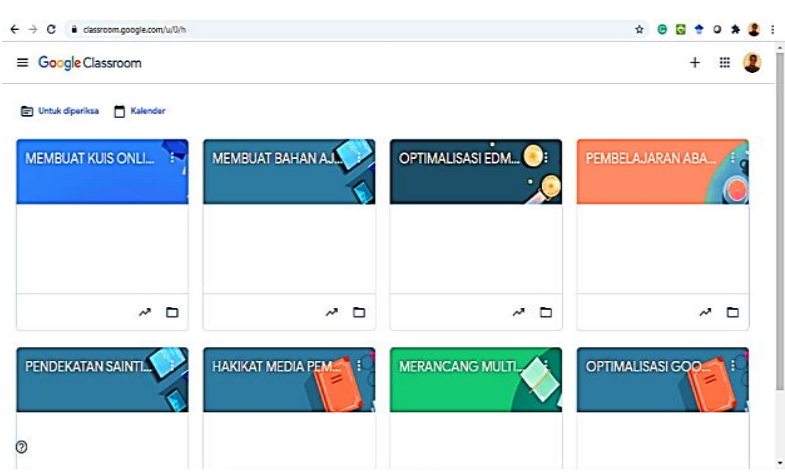

Gambar 3. Google Classroom display before revision

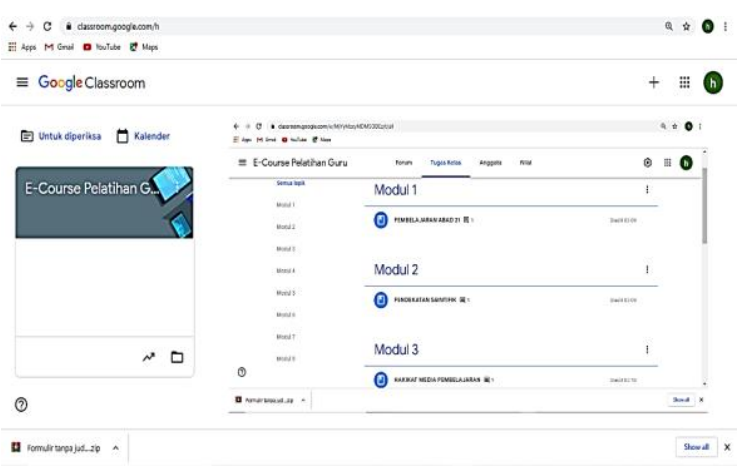

Figure 4. Google Classroom display of all materials

\section{Discussion}

Teachers who were subject to one-to-one stages give advice not to have too many classes. Classes that many trouble teachers to access one by one e-course material. In addition to these suggestions, the teacher advises that video tutorials contained in Google Classroom were made separately following competency achievement indicators because this causes videos to be slow to be accessed. In the limited 
trial stage(small group), the researcher conducts training for teachers through the Google Classroom ecourse. Researchers began briefing teachers on how to use Google Classroom, and then teachers worked training on Google Classroom. At this stage, the teachers took 14 days to complete 8 modules. During the implementation of small groups, most teachers did not experience technical difficulties related to the use of google classroom. But the teacher conveyed the technical obstacles faced when accessing the Google Classroom e-course caused by an unstable internet network. Based on the questionnaire analysis that teachers have filled out, it can be stated that the Google Classroom e-course that has been developed meets the practicality aspect with a percentage of 92.5. The small group results were used to revise prototype II to get prototype III as the final prototype (product).

Infield tests(field tests) obtained an average item of PK component by $85.57 \%$, liability item of TK component $84.2 \%$, liability item of CK component $82.3 \%$, capacity item of PCK component $83 \%$, capacity item of TCK component $82 \%$, capacity item of TPK component $84.6 \%$, and capacity item of TPACK component $88.57 \%$. This showed that the Google Classroom e-course developed as a potential effect with categories both to increase the achievement of TPACK participants (teachers). This indicated that the Google Classroom e-course was effectively used for teacher training. Online teacher training can also improve TPACK skills (Heru \& Yuliani, 2020; Ismail \& Imawan, 2021). The use of e-courses that have been developed can help teachers improve TPACK skills. It can be seen from the instrument analysis that the average achievement of TPACK was 82.46, which belongs to the good category. The use of TPACK instruments can improve the pedagogical competence of IPA teachers and make the learning methods used by teachers relevant to learning activities (Wilujeng, Tadeko, \&Dwandaru, 2020). In addition, the use of learning scenarios compiled in TPACK as a learning medium for teachers can help the success of learning and the development of teacher professionalism (Sickel, 2019).

TPACK-based training is an orientation used to describe TPACK that needs development (Tanak, 2020). Therefore, it is necessary to legitimize the TPACK framework on every teacher training to improve teacher skills in integrating TPACK in classroom learning. Successfully integrating technology in learning not only rests on information and communication technology (ICT) facilities, but the increase in teacher compatibility in training activities needs to be supported through teacher training (Karolčík \& Čipková, 2017). Teaching experience, training, facilities and infrastructure, self-efficacy, and motivation positively affect TPACK teachers (Sojanah, Suwatno, Kodri, \&Machmud, 2021).

\section{CONCLUSION}

Online training using the Google Classroom app during pandemic times can be used to improve teacher TPACK achievement. The ability to integrate TPACK in learning was beneficial for the teachers. Google Classroom was useful and practical and provided new conveniences and challenges for teachers to design and implement online learning to run effectively and overcome teacher technical problems in integrating technology in learning. Therefore, the results of teacher training e-course development research using Google Classroom were valid and practical. This potential effect can be used for teacher training as one of the online training alternatives. This development research has limitations only to look at the possible impact of TPACK achievement in general and do not correlate between each component of TPACK. This study can experiment on population and a more comprehensive sample. In addition, it is necessary to develop an e-course that focuses on one particular field of science to see the relationship between TPACK components in detail.

\section{ACKNOWLEDGEMENT}

Thank you to the PP Muhammadiyah Diktilitbang Council. This research was funded by the RisetMu Grant Program Batch 4, PP Muhammadiyah Diktilitbang Council.

\section{REFERENCES}

Ahied, M., Muharrami, L. K., Fikriyah, A., \& Rosidi, I. (2020). Improving Students' Scientific Literacy through Distance Learning with Augmented Reality-Based Multimedia Amid the Covid-19 Pandemic. Jurnal Pendidikan IPA Indonesia, 9(4), 499-511. https://doi.org/10.15294/jpii.v9i4.26123.

Akbar, R. (2016). An Analysis of Selected Eleventh Grade English Textbooks. Journal of English and Education, 2016(1), 109-126. Retrieved from https://media.neliti.com/media/publications/192500-EN-none.pdf.

Albashtawi, A. H., \& Al Bataineh, K. B. (2020). The Effectiveness of Google Classroom among EFL Students 
in Jordan: An Innovative Teaching and Learning Online Platform. International Journal of Emerging Technologies in Learning, 15(11), 78-88. https://doi.org/10.3991/IJET.V15I11.12865.

Anggraeni, S. W., Alpian, Y., \& Kodariah, S. (2021). Primary School Students' Learning Anxiety during the Covid-19 Pandemic. International Journal of Elementary Education, 5(1), 1-10. Retrieved from https://ejournal.undiksha.ac.id/index.php/IJEE/article/view/33036.

Arikunto, S. (2012). Dasar-Dasar Evaluasi Pendidikan. Jakarta: Bumi Aksara.

Asmuni, A. (2020). Problematika Pembelajaran Daring di Masa Pandemi Covid-19 dan Solusi Pemecahannya. Jurnal Paedagogy, 7(4), 281. https://doi.org/10.33394/jp.v7i4.2941.

Azzahra, N. F. (2020). Mengkaji Hambatan Pembelajaran Jarak Jauh di Indonesia di Masa Pandemi Covid-19. Retrieved from; https://repository.cips-indonesia.org/media/309163-mengkaji-hambatanpembelajaran-jarak-jau-99409337.pdf.

Bahador, Z. bin, Othman, N. bin, \& Saidon, M. K. bin. (2018). Faktor-Faktor yang Mempengaruhi Pengintegrasian Teknologi Pengajaran Berdasarkan Model TPACK dalam Kalangan Guru Matematik. Proceedings of the ICECRS, 1(2), 66-73. https://doi.org/10.21070/picecrs.v1i2.1438.

Eichelberger, A., \& Leong, P. (2019). Using TPACK as a Framework to Study the Influence of College Faculty' S Beliefs on Online Teaching. Educational Media International, 56(2), 116-133. https: //doi.org/10.1080/09523987.2019.1614246.

Gita, S. D., Annisa, M., \& Nanna3, W. I. (2018). Pengembangan Modul IPA Materi Hubungan Makhluk Hidup dan Lingkungannya Berbasis Pendekatan Kontekstual. LENSA (Lentera Sains): Jurnal Pendidikan $I P A, 8(1), 28-37$.

Gunawan, F. I., \& Sunarman, S. G. (2018). Pengembangan Kelas Virtual dengan Google Classroom dalam Keterampilan Pemecahan Masalah (Problem Solving) Topik Vektor pada Siswa SMK untuk Mendukung Pembelajaran. Prosiding Seminar Nasional Pendidikan Matematika Etnomatnesia.

Heru, \& Yuliani, R. E. (2020). Pelatihan Pengembangan Bahan Ajar Multimedia Pembelajaran Interaktif Berbasis Pendekatan Saintifik Menggunakan Metode Blended Learning bagi Guru SMP / MTs Muhammadiyah Palembang. Jurnal Pengabdian Pada Masyarakat, 5(1), 35-44.

Ismail, R., \& Imawan, O. R. (2021). Meningkatkan Penguasaan TPACK Guru di Papua melalui Pelatihan Pembuatan Video Pembelajaran pada Masa Pandemi Covid-19. Jurnal Masyarakat Mandiri, 5(1), 277-288.

Karolčík, Š., \& Čipková, E. (2017). Attitudes among Chemistry Teachers towards Increasing Personal Competencies in Applying ICT. Chemistry-Didactics-Ecology-Metrology, 22(1-2), 99-121. https://doi.org/10.1515/cdem-2017-0006.

Kıray, S. A., Çelik, İ., \& Çolakoğlu, M. H. (2018). TPACK Self-Efficacy Perceptions of Science Teachers: A Structural Equation Modeling Study. Nature, 43(195), 253-256. https: //doi.org/10.1038/120105a0.

Kumar, N., Rose, R. C., \& D'Silva, J. L. (2008). Teachers' Readiness to Use Technology in the Classroom: An Empirical Study. European Journal of Scientific Research, 21(4), 603-616. https://doi.org/10.1504/IJMIE.2008.016228.

Lin, C. Y., Kuo, Y. C., \& Ko, Y. Y. (2015). A Study of Pre-Service Teachers' Perception of Technological Pedagogical Content Knowledge on Algebra. Journal of Computers in Mathmatics and Science Teaching.

Maharani, N., \& Kartini, K. S. (2019). Penggunaan Google Classroom sebagai Pengembangan Kelas Virtual dalam Keterampilan Pemecahan Masalah Topik Kinematika pada Mahasiswa Jurusan Sistem Komputer. PENDIPA Journal of Science Education, 3(3), 167-173. https://doi.org/10.33369/pendipa.3.3.167-173.

Manalu, E., Silaban, S., Silaban, R., \& Hutabarat, W. (2016). The Development of Chemical Practice Guidebook Colloid System-Based Integrated Contextual Character Values. Jurnal Pendidikan Kimia, 8(2), 87-89.

Marbán, J. M., \& Mulenga, E. M. (2019). Pre-service Primary Teachers' Teaching Styles and Attitudes towards the Use of Technology in Mathematics Classrooms. International Electronic Journal of Mathematics Education, 14(2), 253-263. https://doi.org/10.29333/iejme/5649

Mishra, P., \& Koehler, M. J. (2006). Technological Pedagogical Content Knowledge: A Framework for Teacher Knowledge. Teachers College Record, 108(6), 1017-1054. https://doi.org/10.1111/j.1467-9620.2006.00684.x.

Mishra, Punya. (2019). Considering Contextual Knowledge: The TPACK Diagram Gets an Upgrade. Journal of Digital Learning in Teacher Education, 35(2), 76-78. https://doi.org/10.1080/21532974.2019.1588611.

Misieng, J.-, Ramanair, J., \& Rethinasamy, S. (2018). Measuring Teachers' Readiness to Use Technology. Journal of IT in Asia, 8(1), 7-13. https://doi.org/10.33736/jita.852.2018. 
Msila, V. (2015). Teacher Readiness and Information and Communications Technology (ICT) Use in Classrooms: A South African Case Study. Creative Education, 06(18), 1973-1981. https://doi.org/10.4236/ce.2015.618202.

Munastiwi, E. (2021). Adaptation of Teaching-Learning Models Due to Covid-19 Pandemic: Challenge Towards Teachers Problem-Solving Skills. Jurnal Ilmiah Sekolah Dasar, 5(1), 33-44.

Plomp, T. (2007). Educational Design Research: an Introduction. In An Introduction to Educational Design Research (pp. 9-35).

Putra, K. D. P., \& Wulandari, I. (2021). Teacher's Perceptions of Online Learning Activities During the Covid-19 Pandemic. Jurnal Ilmiah Sekolah Dasar, 5(1), 110-118. Retrieved from https://ejournal.undiksha.ac.id/index.php/JISD/article/view/32006.

Restiana, N., \& Pujiastuti, H. (2019). Pengukuran Technological Pedagogical Content Knowledge untuk Guru Matematika SMA di Daerah Tertinggal. Mosharafa: Jurnal Pendidikan Matematika, 8(1), 8394. https://doi.org/10.31980/mosharafa.v8i1.407.

Schmidt, D. A., Baran, E., Thompson, A. D., Mishra, P., Koehler, M. J., \& Shin, T. S. (2009). Technological Pedagogical Content Knowledge (Track): The Development and Validation of an Assessment Instrument for Preservice Teachers. Journal of Research on Technology in Education, 42(2), 123149. https://doi.org/10.1080/15391523.2009.10782544.

Sickel, J. L. (2019). The Great Media Debate and TPACK: A Multidisciplinary Examination of the Role of Technology in Teaching and Learning. Journal of Research on Technology in Education, 51(2), 152165. https://doi.org/10.1080/15391523.2018.1564895.

Sintawati, N. P., \& Margunayasa, I. G. (2021). Interactive E-Module for Science Learning Content : Validity and Feasibility. International Journal of Elementary Education, 5(1), 19-29.

Sojanah, J., Suwatno, Kodri, \& Machmud, A. (2021). Factors Affecting Teachers' Technological Pedagogical and Content Knowledge (A Survey on Economics Teacher Knowledge). Cakrawala Pendidikan, 40(1), 1-16. https://doi.org/10.21831/cp.v40i1.31035.

Sugiyono. (2016). Metode Penelitian Kuantitatif, Kualitatif, dan R \& D. Bandung: Alfabeta.

Sulistiyono, J. (2020). Model Manajemen Pelatihan TIK “DFH (Daring from Home)" Guru SMA Negeri di Kota Semarang. Didaktikum, 20(2), 1-9.

Supriyadi, S., Bahri, S., \& Waremra, R. S. (2018). Kemampuan Technological Pedagogical Content Knowledge (TPACK) Mahasiswa pada Matakuliah Strategi Belajar Mengajar Fisika. Jurnal Inspirasi Pendidikan, 8(2), 1-9. https://doi.org/10.21067/jip.v8i2.2632.

Tanak, A. (2020). Kasetsart Journal of Social Sciences Designing TPACK-Based Course for Preparing Student Teachers to Teach Science with Technological Pedagogical Content Knowledge. Kasetsart $\begin{array}{llll}\text { Journal of Social } & \text { Sciences, } & \text { 51(1), }\end{array}$ https://doi.org/https://doi.org/10.1016/j.kjss.2018.07.012.

Termit Kaur, R. S., \& Samli, C. (2014). Teacher Readiness on ICT Integration in Teaching-Learning: A Malaysian Case Study. International Journal of Asian Social Science, 4(7), 874-885. Retrieved from http://www.aessweb.com/journals/5007\%0ATEACHER.

Tessmer, M. (1999). Planning and Conducting Formatif Evaluations. London: Kogan Page.

Vaganova, O. I., Smirnova, Z. V., Vezetiu, E. V., Kutepov, M. M., \& Chelnokova, E. A. (2020). Assessment Tools in E-Learning Moodle. International Journal of Advanced Trends in Computer Science and Engineering, 9(3), 2488-2492. https://doi.org/10.30534/ijatcse/2020/01932020.

Wilujeng, I., Tadeko, N., \& Dwandaru, W. S. B. (2020). Website-Based Technological Pedagogical and Content Knowledge for Learning Preparation of Science Teachers. Cakrawala Pendidikan, 39(3), 545-559. https://doi.org/10.21831/cp.v39i3.31228.

Yulianti, D., Utami, N. R., Ridloand, S., \& Isdaryanti, B. (2021). Measurement of TPACK Self-Efficacy for PreService Science Teachers. Journal of Physics: Conference Series, 1918(5), 052084. https://doi.org/10.1088/1742-6596/1918/5/052084. 